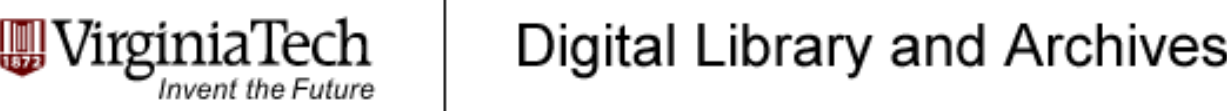

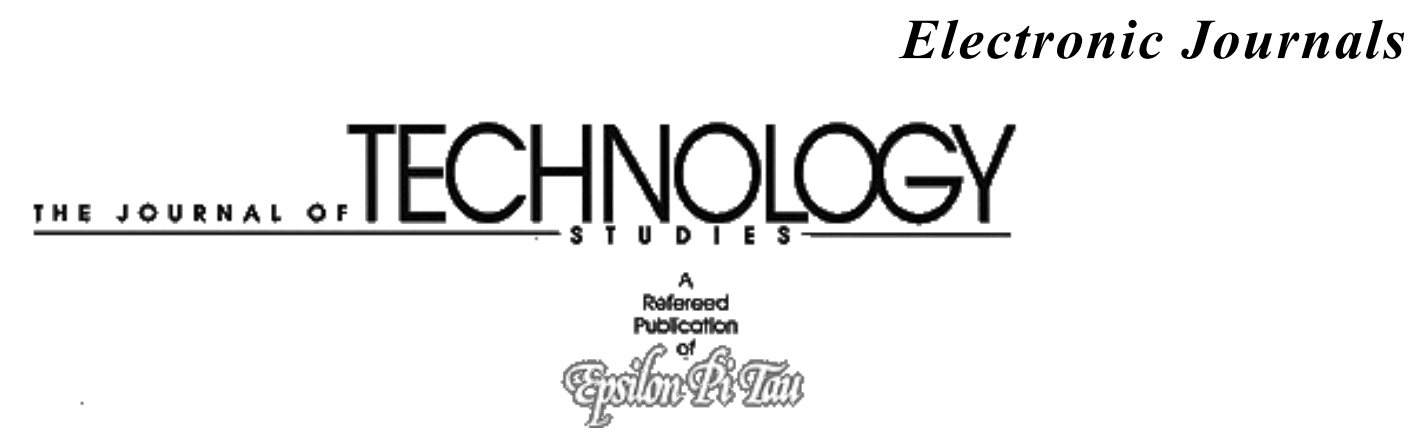

Current Editor: Charles V. Schwab

jots@bgsu.edu

\section{Gender Disparity in Third World Technological, https://doi.org/10.21061/jots.v27i2.a.1 Social, and Economic Development}

\begin{abstract}
Anthony I. Akubue
Despite their seemingly intractable problems, Third World countries have made remarkable progress in improving the well- being of their people in recent decades. In what seems a recurring observation in its annual Human Development Reports, the United Nations Development Program (UNDP) notes that the human progress that developing countries achieved in a period of three decades took the industrialized countries a century to attain. People are living longer, infant mortality rates and illiteracy rates have declined significantly, and appreciable improvements in basic-needs fulfillment of citizens have been realized. A troubling concern, however, is the notion that gains from progress have not been equally beneficial to the genders. Males tend to be better off in most cases, often capturing a disproportionate share of the proceeds than females. There is much evidence in support of the claim that women are in the majority of the poor in the Third World today. According to the UNDP ( 1995 ), 70\% of an estimated 1.3 billion people living in poverty worldwide are women, most of them living in developing countries. However, the feminization of poverty is not so much about more women than men being poor, but about the "severity of poverty and the greater hardship women face in lifting themselves and their children out of the trap" ( UNDP, 1997, p. 64 ). This differential gender impact underlies the UNDP ( 1997 ) statement that "for too long it was assumed that development was a process that lifts all boats, that its benefits trickled down to all income classes-and that it was gender neutral in its impact. Experience teaches otherwise" ( $p$. $1)$.

This article is about Third World women in relation to technological and socioeconomic progress. It examines the differential gender outcome of this progress and probable causes. Nzewi ( 1996 ) attributed obstacles to women engaging in and pursuing careers in science, technology, and mathematics (STM) to factors of tradition and cultural norms, attitudes and prejudices, religion, poverty, and ignorance. Inherent in the socialization process of societies is a particularly damaging depiction of gender roles as biological rather than social constructs. The power of the socialization process in inhibiting women's education in science, engineering, mathematics, and technology education is often underestimated and has not received the attention it deserves among professionals in the field. The view espoused in this article is that this indoctrination inspires phobia, diffidence, and lack of interest among girls and women, who tend to believe that some academic disciplines and professional careers are beyond their abilities. This mindset is a
\end{abstract}


powerful force that is contributing to the perpetuation of poverty among Third World women in particular and the Third World in general. Logic provides that peace cannot endure where poverty prevails, and that the poor will migrate toward relief if relief does not come to them.

\section{Some Background}

Investigations into women's issues in relation to technological, social, and economic progress have been relatively recent, but rural women have for years been affected one way or another by modern technology and development. Women and girls in Third World societies are more likely than men and boys to have less access to technology, education, technical training, land, credit, and basic needs. Historically, women have performed mostly laborious, gender-assigned duties with skills and tools passed down from generation to generation. The duties of Third World women can be placed into three categories: reproductive and nurturing, family and household management, and productive and/ or income-generating roles ( Momsen, 1998 ; UNDP, 1997 ). Studies have shown that in developing countries women, especially poor women, work an average of 12 to 18 hours a day compared to an average of 8 to 12 hours a day for men ( Jacobson, 1993 ; Momsen, 1998 ). Among the tasks women perform are subsistence farming, food production and processing, traditional weaving and sewing, soap-making, petty trading, craft-making, baking, shop-keeping, procuring energy fuel and water, household work, payment of child- ren's school fees, animal care, caring for the elderly, and raising children ( Akubue, 1995 ).

My use of the term "Third World" was as a result of my research of its origin and meaning Alfred Sauvy
coined it in the early 1950s as a forward looking and hopeful way of describing what was taking place in
Africa and Asia in their quest for political independence. Like the Third Estate of pre-Revolutionary
France and its role in the French Revolution, the Third World possessed a revolutionary potential to rise
in rebellion against foreign rule and domination. This prediction materialized with the formation of the
Non-Aligned Movement, a nationalist organization, in 1961. According to one writer, the Third World
became a positive concept symbolizing the new and experimental arena of global politics of neither
capitalist nor communist ideology. This is why I use the term, even though the 1989 fall of communism
(the Second World) prompted calls for its discontinued use. Many leaders from the Third World continue
to prefer that name to others.

\section{Access to Productive Resources}

The gap between male and female literacy rates in the Third World has been narrowing, although female illiteracy continues to be higher than male illiteracy. Out of an estimated 840 million illiterate adults in the developing world, 538 million of them are women. The female illiteracy rate stands at about $39 \%$ in contrast with a male illiteracy rate of 21\% ( Momsen, 1998 ; UNDP, 1997 ). Women and girls tend to receive less education and training than men and boys in most Third World societies ( Herz, 1989). This is not surprising because in the absence or poor enforcement of legislation on compulsory education for all children, coupled with the tendency to value sons over daughters, girls are less likely than boys to go to school. Investments in education continue to be higher for sons than for daughters. This is in spite of studies showing that the education of girls tends to produce far-reaching socioeconomic benefits for the girls and women themselves, their families, and the society in general ( Bellew, Raney, \& Subbarao, 1992 ; Hadden \& London, 1996 ; Herz, 1989 ; Summers, 1992 ). Indeed, most studies have revealed that when schools open their doors wider to girls and women, as well as boys and men, the benefits multiply. Dr. J. E. Aggrey, an eminent educator from Ghana, observed that "if you educate a man, you simply educate an individual, but if you educate a woman, you educate a family" ( Topouzis, 1990, p. 62 ). Among the short-term benefits of educating girls and women are smaller families, better spacing of births, healthier children, less economic dependence, and less vulnerability to abusive spouses. "These initial gains seem also to be readily translated into a range of longer-term benefits that include longer life expectancy, declines in overall mortality rates, and improvements in both social and economic development rates" ( Hadden \& London, 1996, p. 43 ).

Increasingly, parents in Third World societies are realizing the importance of educating their daughters, but there are still some impediments. Not only are there more illiterate women than there are illiterate men, but also two thirds of the children not enrolled in school are girls ( Momsen, 1998 ). 
As much as women would like to participate in adult literacy programs, their incredible responsibilities and workloads keep them from taking advantage of opportunities. The persistence of poverty among many families also works against the education of girls and women. Due mostly to hardship in poor households, girls are more likely than boys to stay at home to help their mothers with income-earning efforts and other household chores. "In fact, the increasing tendency in many areas of keeping girls out of school to help with their mothers' work virtually ensures that another generation of females will grow up with poorer prospects than their brothers" ( Jacobson, 1993, p. 75 ). The concern for the safety of daughters is another critical factor in the decision whether to send girls to school. Their vulnerability, the fear of becoming victims of rape, and a strong taboo on pregnancy out of wedlock are reasons to shield girls from the vagaries of life outside the home. In some societies, parents see educating girls as an exercise in futility since they are given away in marriage and the reward of years of education may elude the natal family. Lastly, the impact of colonial perspectives on gender roles continues to influence gender educational opportunities. A curriculum that emphasizes housework, for instance, does not help women improve their capabilities as farmers. This curriculum is, however, sustained on the premise that humanity would be best served if women could "improve the way in which they cared for their children and catered for the family needs. As a result family welfare programs were devised which gave women instruction in home economics, in improved nutrition, health, and hygiene" ( Young, 1993, p. 19 ). Yet, women play an indispensable role in food production and processing in Third World countries. For example, women in Africa produce $80 \%$ of domestically consumed food, $70 \%$ to $80 \%$ of food crops grown on the Indian sub-continent, and about 50\% in Latin America and the Caribbean ( Jacobson, 1993 ; Momsen, 1998 ). Estimates from Kenya suggest that providing women with the same access to factors and inputs as men would increase the value of their output nearly $22 \%$ ( World Bank, 2000 ).

The agricultural extension service is overwhelmingly a male-dominated profession in the Third World; only $13 \%$ of the agents in the late 1980 s and early 1990 s were women. In the continent of Africa and India, the statistics were as meager as $7 \%$ and $0.5 \%$, respectively ( UNDP, 1995 ). Trained and equipped usually in urban environments still laden with vestiges of colonialism, male extension agents are, not surprisingly, partial to men, even in areas where women are responsible for major cash or food crop production. A study of the pattern of visits by extension workers to farmers in Kenya showed that $49 \%$ of the female-operated farms were never visited by an agent in contrast with only $28 \%$ of male or jointly operated farms ( Momsen, 1998 ). The gender bias against women is further compounded by cultural and religious practices that prohibit direct contact between women and male strangers/extension agents ( Akubue, 1995 ; Young, 1993 ). Moreover, with a ratio of one extension agent to 2,000 or 3,000 farmers, extension systems in many Third World countries are severely constrained and understandably cannot meet the overwhelming demand for their services. The situation is quite the opposite in Europe and North America, where one extension agent serves 300 to 400 farmers ( Quisumbing, 1998 ). Under this condition, it is often assumed that husbands would pass information on to their wives from extension service workers. Studies in Asia, Africa, and Latin America and the Caribbean, however, show that such information communicated indirectly is often distorted and less accurate (Akubue, 1995 ). According to studies in Kenya, "women farmers generally adopt the advice given by extension agents; where they do not, the principal reason they cite are lack of credit and income to buy inputs, and lack of enough land" ( Herz, 1989, p. 44 ).

Generally, rural financial institutions still prefer and require land title as collateral for loan extension in many Third World countries. This requirement tends to be partial to male borrowers, since land ownership and title in most cases belong to men ( Akubue, 1991). "In the patrilineal cultures found in Bangladesh, India, Pakistan, much of sub-Saharan Africa, and Latin America, women gain access to land only through their husbands or sons" ( Jacobson, 1993, p. 70 ). This has not always been the traditional system of land tenure in the Third World. The current system is very much the result of European views of what constitutes gender-appropriate roles, which replaced a precolonial system of communal land ownership. To implement the new system, colonial administrations registered communal land and made land titles out in men's names ( Momsen, 1991 ; Quisumbing, 1998 ; Young, 1993 ). Contemporary Third World development professionals have tacitly endorsed past actions by maintaining the status quo. For most rural women, access to land is usually in the form of user rights rather than absolute ownership rights ( Quisumbing, Brown, Feldstein, Haddad, \& Pena, 1995 ). In instances where women have ownership rights, their share is usually small relative to men's. Lacking outright land ownership and land title commonly required by banks for loan extension almost guarantees lack of funding for the women. The 
traditional moneylenders' practice of charging usury rates is an exorbitant and exploitative alternative source of credit. Without a propitious rural financial market to count on, women have difficulty mobilizing enough start-up capital for new businesses or expanding existing undertakings. Women, like men, need credit to acquire essential appropriate technology, tools, and material input to improve productivity, profits, and standard of living. Not surprisingly, the cumulative effects of protracted denial of women's access to productive resources, education, and training are worsening gender disparity and inequity.

\section{The Impact of Technological, Social, and Economic Development}

Not having as much access as men inhibits rural women's technological literacy and, definitely, their motor, cognitive, and interpersonal communication skills. Consequently, some researchers have contended that the "most common result of 'development' is to relegate women to the subsistence sector in agriculture and low- paying jobs in manufacturing and industry" ( Tadesse, 1982, p. 79 ). Manufacturing and Industry Technological development in the modern industrial sector unmistakably has opened up diverse job opportunities for Third World women. However, questions have been raised about the quality of the jobs thus created. These have been mostly low-wage, low-skill, dead- end jobs where they are easily dispensable. Lacking the necessary skills and specialization, women workers in modern sector factories "mostly are engaged in non-technological gathering, assembling, arranging and packaging activities and therefore technical skills are not being transferred equally to men and women" ( Srinivasan, 1981, p. 91 ).

Regardless of what they are called, maquiladoras in Mexico or export processing zones (EPZs) elsewhere in Latin America, Africa, and Asia, they are industrial plants owned or subcontracted by multinational corporations with headquarters in the industrialized nations. They are export- oriented assembly and manufacturing firms producing goods primarily for re-export to Europe and North America. These industrial plants, predominantly electronics, textiles, apparel, and footwear industries, hire mostly female labor ( Akubue, 1995 ; Momsen, 1998 ). It is claimed that women have a number of attributes that are not commonly exhibited by men. Women are said to be nimble-fingered, dexterous, docile, patient, and obedient, and to possess better attention spans than men do. Interestingly, these fine characteristics have contributed significantly to women's vulnerability in the maquiladoras or EPZs.

As manufacturing with laborsaving, capital-intensive technology has grown in the maquiladoras and EPZs, the traditional labor- intensive assembly for which they are known no longer enjoys the monopoly it once did, and the characteristic female labor dominance is on the wane. For example, the percentage of female workers in the Mexican maquiladoras fell from a 1982 figure of $77 \%$ to $61 \%$ in 1990 ( Wilson, 1992 ). Also, cases of sexual harassment and molestation, as well as inhumane and unhealthy working conditions, are not uncommon at these enterprises ( Kelly, 1983 ; Pena, 1997 ). Mitter ( 1995 ) conceded that jobs in the factories are not perfect, but argued that the "conditions of employment are superior to alternatives that women are likely to find as domestic workers, prostitutes, or as workers in the informal sector" ( p. 23 ). This assertion is reasonable but only to the degree that one believes that half a loaf of bread is better than no bread at all.

Utilizing women to the extent of their potential in all spheres of life is not a matter of doing them a favor, but engaging the enormous human resource of one half of humanity for the betterment of communities and nations. A study of women workers in the Dominican Republic shows that they are usually fired when they fail to meet increasing output quotas, get married, or become pregnant ( Momsen, 1998 ). Paradoxically, the so-called advantages of the female gender have merely served to congregate women at the lower rungs of the organizational ladder and increase their vulnerability. The situation is not much different for women in the mechanized agricultural sector.

\section{The Agricultural Sector}

It is not unusual for the introduction of a new farm technology to result in radical shifts in gender roles in agricultural labor. Anderson ( 1985 ) stated that "when a technology is introduced, those who either already enjoy higher status or who are in a position to corner it may move into tasks that were previously low status when done without the benefit of the new technology" ( p. 61 ). Since men are more likely than women to have access to technology and associated technical training, any shifts in sex roles due to new agricultural technologies would tend to favor mostly men. Momsen ( 1991 ) argued similarly that the "introduction of a new tool may cause a particular job to be reassigned to the opposite sex and men tend to 
assume tasks that become mechanized" ( p. 50 ). Thus the introduction of post-harvest food processing technologies may mean the loss of a traditional source of income for rural poor and landless women. For example, women who depend on the traditional hand pounding with mortar and pestle to de-husk rice or grain as hired labor may lose their job as a result to rice, corn, or oil mills operated by men. This is especially the case in Africa and Asia, where many women fit into this category of hired rural labor ( Momsen, 1991 ; Quisumbing et al., 1995 ).

In rural West Africa, hired female labor process palm nuts and kernels for the extraction of widely consumed palm oil. Most of these women lost their jobs with the introduction of oil mills operated by men. Still, for Moslem women restricted by purdah from work outside the homestead and in the company of men, technology-induced relocation of the workplace to the mills may mean the loss of a vital source of income. Furthermore, while male landowners in Africa and elsewhere experienced lightened workload and expansion in cash crop cultivation with modern tractors and improved animal-powered farm equipment, work for their wives increased, with more area to weed, hoe, and plant ( Jacobson, 1993 ). A study of a Tiv farm development project in Nigeria showed that women experienced "a disproportionately high share of the labor increase without a corresponding increase in income. Female labor requirements rose by $17 \%$, while those of men rose by only 6\%" ( Young, 1993, p. 52 ). These conditions for women simply cannot be dismissed as fortuitous and without connection to existing power relations and decision-making processes in the Third World.

\section{Decision Making}

It appears from the above that technology and development have actually been contributing to widening the gender gap instead of reducing it. The general image of technological and socioeconomic development is and has been that of a male directed and controlled process. Seen as such, development has commonly been viewed as a process that is structured by men and for men, and women are expected to abide without questions. The literature is replete with evidence that women are often not involved or consulted in the planning and designing of technology-based development projects and programs with direct impact on them. For instance, projects involving solar cookers in India, hydraulic palm oil presses in Nigeria, and high yield variety maize in Mexico were implemented with little input from women who are and have traditionally been responsible for cooking and palm oil processing. The introduction of solar cookers in India, Kenya, and elsewhere seems expedient given the serious problems of deforestation and fuelwood scarcity. As logical as this innovation seemed, rural women resisted it mainly because of their labor patterns, food habits, and the intermittent nature of the sun. For instance, women cook the main meal of the day when they return from the farms in the evening. The solar cooker is not very useful at sunset, and it is highly unlikely that some women would readily abandon established labor patterns in the village to accommodate a new technology. Furthermore, since the solar cooker must face directly into the sun to be effective, it requires constant relocation to track the sun as it changes positions. This is inconvenient, to say the least. Finally, even though some governments subsidize the cost of solar cookers as in India for instance, the price remained prohibitive for a large number of people ( Blankenberg, 1991 ).

The problems with the introduction of the solar cooker and similar schemes elsewhere were due mostly to flaws in the planning process. As appropriate as the innovations seemed, their planning and introduction lacked the valuable input of the women who are the majority of the target end-users. This mistake is often perpetuated by the erroneous assumption that men who dominate the decision-making process know what women need. The urgency of listening to women articulate their needs and including them in decision-making cannot be overemphasized. As the saying goes in India, "As a bird cannot fly on one wing, no society can make progress unless its women too join men in all activities" ( Bhattacharya \& Bose, 1995, p. 93 ). Science and technology have become the most potent sources of change and empowerment in modern society. To insist on the age-old practice of excluding women in decisions concerning their development is to be unwise and myopic.

Women are conspicuously under- represented in decision and policy making concerning technological and socioeconomic development. Explaining the reason for this condition, Young ( 1993 ) suggested plausibly that development practitioners are cautious not to violate what may be strongly regarded cultural practices and values. Mostly male- dominated government officials from the Third World often claim that concerns about the absence of women at high levels of government and their lack of active involvement in policy making is a Western preoccupation of no interest even to their women. The few women in positions 
of power and authority are being lost through attrition as many of them experience first-hand what it entails to be "lonely at the top." However, efforts to improve the status of women and to enlist their selfconfidence, intellectual, and decision-making capabilities for the benefit of society have culminated in landmark conferences and policy adjustments worldwide.

\section{Confronting Gender Bias}

As a result of concerted efforts in recent decades, the plight of women in general is a topic of serious research, discourse, and action worldwide. Various governments are cooperating with international agencies to initiate gender sensitive policies and programs. For instance, in 1973, the U.S. Congress adopted the Percy Amendment (Section 113 of the 1973 Foreign Assistance Act) sponsored by Republican Senator William Percy (retired) of Illinois. As the amendment requires, U.S. bilateral development assistance "shall be administered so as to give particular attention to those programs, projects and activities which tend to integrate women into the national economies of foreign countries, thus improving their status and assisting the total development effort" ( Blumberg, 1990, p. 2 ). The amendment also directed the U.S. Agency for International Development (AID) to include the likely effects of development projects on women in its feasibility studies of projects. The Women in Development (WID) Office of the AID was established in direct response to this amendment. The office assists in the preparation and testing of case studies involving projects funded by the AID. This legislation was unprecedented in its strong endorsement of women

as contributors and agents of economic development as well as its beneficiaries. Planners, therefore, must guard against the negative effects of their projects on women and focus on the need to enhance women's productivity, raise their income, and promote their access to economically productive resources as a means to achieving overall national economic growth. ( Overholt, Anderson, Cloud, \& Austin, 1985, p. 11 )

Similar efforts followed the U.S. example. The British Commonwealth, for example, in 1980 established a Women and Development (WAD) program that received the endorsement of all of its member nations ( Momsen, 1991 ). Third World governments have also initiated pragmatic educational reforms that are having positive impact on their literacy rates. More girls and young women are enrolling in schools today than ever before. The combined female primary and secondary enrollment in the developing world jumped dramatically from $38 \%$ in 1970 to $68 \%$ in 1992 ( UNDP, 1995 ). Governments have also been working in alliance with multilateral agencies in the march toward gender equality.

The United Nations has been and remains an active agent of change in its global work on gender matters. The World conferences on women held in Mexico City, Mexico, in 1975; Copenhagen, Denmark, in 1980; Nairobi, Kenya, in 1985; and Beijing, China, in 1995 have kept attention focused on the condition of women and produced action plans for improving women's status worldwide ( Kaye, 1995 ; Young, 1993). Not only was 1975 designated International Women's year, the UN Decade for Women, from 1976 to 1985, started with the creation by the UN General Assembly of a Voluntary Fund for the decade that became known as the UN Fund for Women (UNIFEM). UNIFEM's efforts are focused on three areas: strengthening women's economic capacity as entrepreneurs and producers, promoting governance and leadership that increase women's participation in decision-making processes that shape their lives, and promoting women's human rights ( "UNIFEM," 1998 ). The 1975 conference in Mexico adopted the World Plan of Action (WPA) from the UN.

The WPA is a compendium of objectives encompassing priority issues such as enabling "educational opportunities for women, better employment prospects, equality in political and social participation, and increased welfare services" ( Young, 1993, p. 25 ). The subsequent conferences in Copenhagen, Nairobi, and Beijing have been vital to review work in progress, evaluate accomplishments and challenges, pass important resolutions, and develop follow-up action plans. Professional associations also work cooperatively with the UN for gender equality and equity. For instance, the Gender and Science and Technology Association (GASAT) has through its conferences worked toward narrowing the gender gap in relation to increasing female presence in the fields of science and technology education. GASAT made vital contributions towards the inclusion of science and technology in the Platform of Action during the last UN conference on women held in Beijing, China ( GASAT, 1998 ). All this has been impressive, but it goes without saying that this concerted effort to improve the status of women must continue without 
abatement, for there is much more yet to be done.

\section{The Work to Be Done}

Women's positions in most contemporary social institutions in Third World countries continue to be subordinate in many cases and border on tokenism in others. A thorough examination of the cultural and political milieu in educational systems and the workplace is imperative to identify and isolate factors that work against women's enrollment and success in technological fields and their upward mobility in public and private organizations. Any attempt to improve the enrollment of women in fields such as technology education, engineering, and science where they are poorly represented must start with attempts to identify and remove impediments keeping them out of these disciplines. Changes in institutional cultures, societal power relations, social values, and stereotypes are inevitable in this effort. Successfully identified, information about results must be widely disseminated and factored into all future program design and development.

The dissemination of information is crucial and cannot be overlooked in the effort to eradicate gender disparity and improve the status of women in general. Information dissemination will not only reduce the common practice of reinventing the wheel, but will also speed up the adaptation and replication of successful programs as needed in different locations. Due primarily to extensive publicity, highly successful Rotating Savings and Credit Associations (ROSCAs) such as the Grameen Bank of Bangladesh, which provide micro loans to rural women, are increasing in number and have been very effective in empowering women ( Akubue, 1991 ). ROSCAs have enabled rural women, denied loans from conventional financial institutions for lack of collateral and track records, to purchase low-cost appropriate technologies for new businesses or to expand existing ones. Looms, hand-sewing machines, improved cooking stoves, hand grinders, manual typewriters, and hand tools are some examples of appropriate technologies purchased with loans from ROSCAs.

Programs in Mexico and Jamaica, for instance, teach young, unemployed, low- income women technical skills for jobs traditionally associated with the male gender. With assistance from UNIFEM, 10 women from Tempoal in Mexico started a thriving manufacturing enterprise after receiving training as welders and machinists in Colombia, South America. The women started a company to manufacture simple, easily affordable water pumps for export and domestic sale in Mexico. In the Caribbean island of Jamaica, a skill-developing training program that prepares women for careers in the construction industry is known for its high job placement rates ( Antrobus \& Rogers, 1980 ; Dorman, 1991 ; McLeod, 1986 ). The success of these programs is a strong testimony that gender roles are primarily social constructs as opposed to indelible biological impositions. Associations such as the GASAT remain unwavering in their belief that given a level playing field, women are quite capable of mastering the skills for careers in science, technology, and mathematics.

However, more extensive improvements in gender equality are possible if the replication of successful projects is executed in tandem with other strategies. Famous professional women can be enlisted as role models in a multifaceted strategy especially to inspire young women to pursue academic education and careers in traditionally male-dominated fields such as technology education, engineering, and computer science. Even in the United States where parity in literacy rates has been achieved between the genders, women still constitute a very small percentage of students graduating with bachelor's degrees in engineering and computer science. Only $9 \%$ and $29 \%$ of students who earn bachelor's degrees in engineering and computer science, respectively, are women ( Rengel, 2000 ). Using famous women engineers, technologists, and scientists as role models, young women can be encouraged to enroll in related majors. For instance, Sarah Akbar of Kuwait Oil Company was a petroleum engineer and a member of the Kuwaiti team of firefighters who fought the inferno at Kuwait oil wells when operation Desert Storm ended in 1991. Sarah was the first woman ever in Kuwait and in the Middle East to participate in a potentially hazardous task of that kind. The publicity that followed Sarah's bravura turned her into a role model, symbol of equality, and mentor for young Kuwaiti women. A study at Kuwait University later showed that the number of women enrolled in petroleum engineering increased substantially since Sarah's unprecedented feat ( Soliman, 1993 ). Sarah's efforts were a lesson in self-confidence, courage, and risk-taking for women, and another refutation of the theory that we are born with naturally assigned, not to speak of unchangeable, gender roles. However, to be effective, the task of collecting and making this and other successful schemes available for dissemination must be the responsibility of a central body 
established and supported by governments in the Third World. Centers for the collection and dissemination of information on effective strategies for improving women's status and achieving gender equality have been set up in many Third World countries in recent years. Women's bureaus "collate, collect and coordinate existing information as well as encourage, fund and partially direct future research" ( Nelson, 1981 , p. 49 ). The charge of most women's bureaus is not only to ensure that women play a greater, and important, part in all development projects, but also to plan, coordinate, and monitor a wide variety of other projects having to do with women. To this end, women's bureaus act as catalysts integrating women into male-dominated areas such as the agricultural extension profession. Making sure that women are recruited and trained includes educating male colleagues on respect for and sensitivity to issues concerning women. Women's bureaus and similar agencies are definitely a welcome idea, but they can be subverted by inadequate funding, lack of trained personnel, and having little or no political clout. According to Young ( 1993 ), many of these agencies have not been very effective for these reasons.

Finally, socialization in traditional societies often includes risk aversion for women. The march toward gender equality will be better served with strategies that assist women to unlearn years of belief that risk-taking is improper for the female gender. Being able to give up what one "is" for what one "could become" is the essence of risk-taking. Women are by tradition and mores more likely than men to avoid taking risks for fear of failing. It is important to point out here that failure is itself an important aspect of the learning process. Properly managed, failure can be a positive guide to success. The notion of doing things for instead of with women, the result of the social and cultural orientation in most communities, presents a problem in that it denies them the chance to acquire vital knowledge and contacts. To sincerely work toward a society of gender equality and equity, women have to have access to political and economic networks. Speeches and reports that extol the benefits of gender equality are nothing more than empty rhetoric if they are not followed up with commensurate action. As Jacobson ( 1993 ) aptly remarked, "development strategies that limit the ability of women to achieve their real human potential are also strategies that limit the potential of communities and nations" ( p. 76 ). Those of us in science and technology need to become involved through scholarly papers and presentations to lend credibility and a sense of urgency to the plight of Third World women and girls. In a "shrinking" world made possible through advances in transportation and communications technology, regional problems tend to quickly extend beyond regional boundaries.

\section{Author}

Dr. Anthony Akubue is a professor in the Department of Environmental and Techno- logical Studies at St. Cloud State University. He is a member-at-large of Epsilon Pi Tau.

\section{References}

Akubue, A. I. (1991). Credit for small-scale rural entrepreneurs in the Third World. International Third World Studies \& Review, 3(2), 251-255.

Akubue, A. I. (1995). Technology, women, and development. The Technology Teacher, 55(2), 10-15.

Anderson , M. B. (1985). Technology transfer: Implications for women. In C. Overholt, M. B. Anderson, K. Cloud, \& J. E. Austin (Eds.), Gender roles in development projects (pp. 57-78). West Hartford, CT: Kumarian Press.

Antrobus , P., \& Rogers, B. (1980). Hanover street: An experiment to train women in welding and carpentry. New York: Seeds.

Bellew , R., Raney, L., \& Subbarao, K. (1992, March). Educating girls. Finance and Development , pp. 54-56.

Bhattacharya , B., \& Bose, P. (1995). Role of education and literacy in the development of rural women with special reference to Himalayan region. In A. Bahuguna (Ed.), Science and technology in relation to rural women (pp. 93-99). New Delhi, India: Har-Anand.

Blankenberg, F. P. (1991). Appropriate technology for rural development in India . New Delhi, 
India: Concept.

Blumberg, R. L. (1990, November). Gender matters: Involving women in development in Latin America and the Caribbean (Report No. 70328). Washington, DC: Agency for International Development.

Dorman, J. (1991). Profiles in progress: Working women . Bridgeport, CT: Discovery Channel.

Gender and Science and Technology Association. (1998). Ninth international conference on gender and science and technology. Retrieved from the World Wide Web: http://www.gustavus.edu/ simpson/ gasat/GASAT-9/img001.htm

Hadden , K., \& London, B. (1996). Educating girls in the Third World: The demographic, basic needs, and economic benefits. International Journal of Comparative Sociology , 37(1-2), 31-46.

Herz , B. (1989). Women in development: Kenya's experience. Finance and Development , 26(2), 43-45.

Jacobson, J. L. (1993). Changing the gender gap in development. In L. Starke (Ed.), The state of the world (pp. 61-79). New York: Norton.

Kaye , L. (1995, September). To bear the burden. Far Eastern Economic Review, pp. 42-43.

Kelly , M. P. F. (1983). Gender and industry on Mexico's new frontier. In J. Zimmerman (Ed.), The technological woman interfacing with tomorrow (pp. 18-29). New York: Praeger.

McLeod, R. (1986). The women's construction collective: Building for the future (Issue Brief No. 9). New York: Seeds.

Mitter , S. (1995). Information technology and working women's demand. In S. Mitter \& S. Rowbotham (Eds.), Women encounter technology: Changing patterns of employment in the Third World (pp. 19-43). New York: Routledge.

Momsen, J. H. (1991). Women and development in the Third World. New York: Routledge.

Momsen , J. H. (1998). Gender bias in development. In A. Gonzalez \& J. Norwine (Eds.), The new Third World (pp. 93-111). Boulder, CO: Westview Press.

Nelson , N. (1981). Mobilizing village women: Some organizational and management considerations. The Journal of Development Studies , 17(3), 47-58.

Nzewi , U. (1996). Involving women in science, technology, and mathematics (STM): Obstacles, remedies and challenges for national development . Paper presented at the 8th International Conference of the Gender and Science and Technology Association (GASAT), Ahmedabad, India.

Overholt , C., Anderson, M. B., Cloud, K., \& Austin, J. (1985). Women in development: A framework for project analysis. In C. Overholt, M. B. Anderson, K. Cloud, \& J. E. Austin (Eds.), Gender roles in development projects (pp. 3-15). West Hartford, CT: Kumarian Press.

Pena , D. G. (1997). The terror of the machine: Technology, work, gender, \& ecology on the U. S.-Mexican border. Austin, TX: CMAS Books.

Quisumbing, A. R. (1998). Women in agricultural systems. In N. P. Stromquist (Ed.), Women in the Third World: An encyclopedia of contemporary issues (pp. 261-272). New York: Garland.

Quisumbing, A. R., Brown, L. R., Feldstein, H. S., Haddad, L., \& Pena, C. (1995). Women: The key to food security. Washington, DC: The International Food Policy Research Institute. 
Rengel , M. (2000, August 21). Women trailing in high-tech excitement. St. Cloud Times, p. 6A.

Soliman , A. (Executive Producer). (1993, June 13). CNN world report . Atlanta, GA: Cable Network News.

Srinivasan , M. (1981). Impact of selected industrial technologies on women in Mexico. In R. Dauber \& M. L. Cain (Eds.), Women and technological change in developing countries (pp. 89-108). Boulder, CO: Westview Press.

Summers , L. (1992, August). The most influential investment. Scientific American , p. 132.

Tadesse , Z. (1982). Women and technology in peripheral countries: An overview. In P. M. D'Onofrio-Flores \& S. M. Pfafflin (Eds.), Scientific-technological change and the role of women in development (pp. 77-111) Boulder, CO: Westview Press.

Topouzis , D. (1990, July-August). The feminization of poverty . Africa Report, pp. 60-63.

United Nations Development Program. (1995). Human development report, 1995. New York: Oxford University Press.

United Nations Development Program. (1997). Human development report, 1997. New York: Oxford University Press.

UNIFEM -United Nations Development Fund for Women: Working for women's economic and political empower ment. (1998). WIN News , 24(3), 3.

Wilson, P. A. (1992). Exports and local development: Mexico's new Maquiladoras . Austin, TX: University of Texas Press.

World Bank. (2000). World development report. New York: Oxford University Press.

Young , K. (1993). Planning development with women: Making a world of difference . New York: St. Martin's Press.

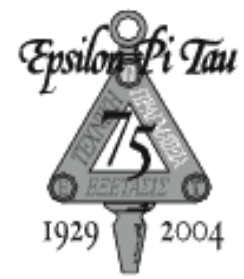

\section{THE INTERNATIONAL HONORARY FOR} PROFESSIONS IN TECHNOLOGY Promoting Excellence in Preparation, Excellence in Practice.

DLA Ejournal Home | JOTS Home | Table of Contents for this issue | Search JOTS and other ejournals 